\title{
MOLLUSCICIDAL AND LARVICIDAL ACTIVITIES OF Atriplex inflata AERIAL PARTS AGAINST THE MOLLUSK Galba truncatula, INTERMEDIATE HOST OF Fasciola hepatica
}

\author{
Néjia HAMED(1), Fatma NJEH(2), Mohamed DAMAK(2), Ali AYADI(1), Raoudha MEZGHANI-JARRAYA(2) \& Hayet HAMMAMI(1)
}

\begin{abstract}
SUMMARY
Fasciolosis is a widespread parasitosis of farm live-stock in many developing countries. For this reason, it is necessary to search for new substances against parasitic diseases caused by flukes. Indeed, a wide variety of terrestrial plants have been subjected to chemical and pharmacological screening in order to discover their potential for human medicinal use. The molluscicidal and larvicidal activities of Atriplex inflata were tested on Galba truncatula and Fasciola hepatica larval stages infecting this snail in Tunisia. Phytochemical tests were conducted on extracts in order to establish a meaningful relationship with molluscicidal and larvicidal activities. The molluscicidal activity was evaluated by subjecting snails to sample aqueous solutions. Accordingly, hexane, ethyl acetate, methanol and methanol-water (8:2, v-v) were used as extraction solvents. As a result, hexane and ethyl acetate extracts showed potent activity, according to the World Health Organization, giving $\mathrm{LC}_{50}=7.59 \mathrm{mg} / \mathrm{L}$ and $6.69 \mathrm{mg} / \mathrm{L}$ for hexane extracts of leaves and fruits, respectively. Ethyl acetate extracts gave $\mathrm{LC}_{50}=5.90 \mathrm{mg} / \mathrm{L}$ and $7.32 \mathrm{mg} / \mathrm{L}$ for leaves and fruits, successively. Molluscicidal activities of powders were less potent on snails, but active according to the World Health Organization. Hexane and ethyl acetate extracts from leaves and fruits gave potent larvicidal activities with a delay rate exceeding $45.50 \%$ (45.50-98.92\%). Phytochemical tests showed that these activities may be attributed to the presence of triterpenoids and/or sterols.
\end{abstract}

KEYWORDS: Environmental Health; Molluscicidal activity; Galba truncatula; Atriplex inflata; Larvicidal activity; Fasciola hepatica.

\section{INTRODUCTION}

Fasciolosis is a serious parasitosis of farm live-stock that is caused by a helminth species Fasciola hepatica ( $F$. hepatica). It is spread world-wide and causes serious economic losses in the industry of animal husbandry (MAGE et al. 2002). Galba truncatula (G. truncatula), also called Lymnaea truncatula, belongs to the Lymnaeidae family and has been identified as the major intermediate host of F. hepatica in southern Tunisia (AYADI et al. 1993, HAMMAMI \& AYADI 1999).

In Tunisia, human fasciolosis is a rare disease; only 38 cases were reported between 1940 and 2007 (AYADI et al. 1991, HAMMAMI et al. 2007). The majority of patients come from the North and Southwest of Tunisia (AYADI et al. 1997). Animal fluke infection, however, is more common, being 20\% in Sajnene (JEMLI et al. 1991) and 44\% in Tozeur (HAMMAMI \& AYADI 1999).

Treatment of fasciolosis requires high or multiple doses of drugs with numerous side effects (ABDUL-SAMIE et al. 2010). Therefore, snail control is considered not only complementary but also essential in fasciolosis control. It is regarded as a rapid and efficient method of reducing or eliminating transmission, as well as breaking up the parasite life cycle (MELLO-SILVA et al. 2006, JIGYASU \& SING 2010). The search for local molluscicidal plants was considered more sustainable than the use of synthetic drugs (HAMMAMI et al. 2011).

Atriplex inflata (A. inflata) showed important biological activities against a large number of pathogens, but no previous investigations on the molluscicidal activity of this plant were established. However, other species of the genus Atriplex showed molluscicidal activities, such as $A$. stylosa and A. hamilus against Biomphalaria alexandrina (BAKRY 2009, TANTAWY 2002). Moreover, it was demonstrated that A. leucoclada and A. nummularia lindleyi had molluscicidal activities (SHOEB et al. 1987; CHRISTENSEN \& OMAR 1985).

Based on these facts and since other species of the genus Atriplex have been described as potent molluscicide plants, rich in saponins, flavonoids and other components, the present study aims to investigate the phytochemical composition, and the molluscicidal and larvicidal activities of hexane, ethyl acetate, methanolic, as well as hydromethanolic extracts from this plant against $G$. truncatula, the intermediate host of $F$. hepatica, so as to contribute to the new area of application of these plant extracts as eco-friendly molluscicides (MELLO-SILVA et al. (2006)).

(1) Faculty of Medicine, Fungal and Parasitic Molecular Biology Laboratory, Sfax, Tunisia. E-mails: nejiahamed@hotmail.com; ayadi.ali@fms.rnu.tn; hayetfss@yahoo.fr (2) Faculty of Science, Laboratory of Chemistry of Natural Products, Sfax, Tunisia. fatma.njeh@gmail.com; mohamed.damak@fss.rnu.tn; Raoudha.Jarraya @fss.rnu.tn 


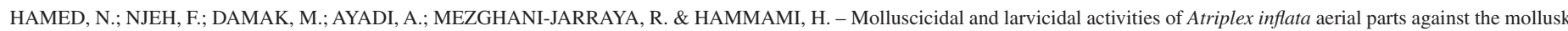
Galba truncatula, intermediate host of Fasciola hepatica. Rev. Inst. Med. Trop. Sao Paulo, 57(6):473-9, 2015.

\section{MATERIALS AND METHODS}

Chemicals: All solvents used for extraction and partitioning were fractionally distilled prior to use.

Plant material: A. inflata F. Muell. = A. lampifer Buxb. $=$ A. lindleyi Moq. = Blackiella inflata $(\mathrm{F}$. Muell.) Aellen belongs to the Chenopodiaceae family. It is also called "Gtaf" in Arabic. This is an Australian plant introduced around 1895 in Tunisia as a forage species and, since then, it has been naturalized in southern Tunisia. It grows in saline soils with fine to medium texture (LE FLOC'H et al. 2010, CHAIEB \& BOUKHRIS 1998).

The plant was harvested in November 2011, from Sfax, Tunisia. The botanical identification was established by Pr. Mohamed Chaieb, Botanist at the Faculty of Sciences of Sfax, Tunisia. The voucher specimen's number LCSN113 was deposited at the Laboratory of Chemistry of Natural Substances in the Faculty of Sciences, University of Sfax, Tunisia.

Extractions: The aerial parts of A. inflata were collected from the coast of Sidi Mansour, Sfax (Latitude: 34.745; Longitude: 10.761) in November, 2011. Once sorted, leaves and fruits were dried in the shade and ground by a mechanical grinder; leaves (125 g) and fruits $(270 \mathrm{~g})$ were partitioned, each by sequential macerations with hexane, ethyl acetate, methanol and methanol-water (8-2: v-v), each for $48 \mathrm{~h}$. A quantity of powder was kept aside for subsequent molluscicide tests. The extracts were filtered and concentrated under reduced pressure in a rotary evaporator, then dried. The dry extracts were subjected to various chemical tests and Thin Layer Chromatography (TLC) to detect the presence of different phytoconstituents.

Phytochemical tests: Plant extracts were tested by phytochemical qualitative reactions for usual plant secondary metabolites. The investigation included triterpenoids and/or sterols, flavonoids, saponins, alkaloids, coumarins, tannins, tropolone nuclei and quinones. Analytical responses were based on color reactions or TLC plate revelation.

Using color reactions: plant extracts were subjected to chemical tests $\left(\mathrm{T}_{1}\right.$ to $\left.\mathrm{T}_{8}\right)$ based on their colors to check for the presence of some phyto constituents. Thus, $1 \mathrm{mg}$ of each extract was dissolved in $1 \mathrm{~mL}$ of the suitable solvent to obtain solution E, which was shaken. Then, the appropriate standard solutions were added to test the presence of sterols and/or triterpenoids ( $\mathrm{T}_{1}$ : Liebermann's reaction), tropolone nuclei ( $\mathrm{T}_{2}$ : Wiustater's reaction), free quinones ( $\mathrm{T}_{3}$ : Borntraeger's reaction), flavonoids $\left(\mathrm{T}_{4}\right.$ : test of flavonoids) and alkaloids $\left(\mathrm{T}_{5}\right.$ : Mayer's reaction).

These tests $\left(\mathrm{T}_{1}\right.$ to $\left.\mathrm{T}_{5}\right)$ were performed according to HARBORNE (1964, 1973).

$\mathrm{T}_{6}$ : Frothing test for saponins according to ONWUKAEME et al. (2007).

$\mathrm{T}_{7}$ : test for coumarins by BÉKRO et al. (2007).

$\mathrm{T}_{8}$ : test for tannins by AKINJOGUNLA et al. (2010).

Using UV detection of TLC plates: additional TLC plate revelation which was done under UV light $(365 \mathrm{~nm})$, whether with or without spraying specific reagents.

* Detection of alkaloids: Dragendorff's reagent (Munier and
Macheboeuf's formula): This reagent reveals alkaloids as red-orange spots in visible light (HARBORNE 1964).

* Detection of saponins: total steroidal saponins appear to be a reddish purple after spraying plates with a chloroform saturated antimony trichloride solution and, a few minutes after heating the plate $\left(100-110{ }^{\circ} \mathrm{C}\right)$, all steroidal nuclei are located without distinguishing saponins from glycoalkaloids (GA) which were already revealed as orange spots by Dragendorff's reagent (HARBORNE 1964).

* Detection of sterols and/or triterpenoids: a range of colors is produced, visible in both daylight and UV, on spraying heated plates for $10 \mathrm{~min}$ at $100{ }^{\circ} \mathrm{C}$ with Carr-Price reagent, i.e. $20 \%$ antimony chloride in chloroform (HARBORNE 1998).

* Detection of flavonoids: $1 \% \mathrm{AlCl}_{3}$ in absolute ethanol reacts specifically with flavonoids yielding a fluorescing complex. It gives well colored yellow visible spots (MARKHAM 1982).

* Detection of coumarins: natural coumarins exhibit fluorescence properties in UV/365 nm. Their spots can be easily detected on TLC plates, without using any chromogenic reagents. Purple and blue colors characterize them (GLOWNIAK 2009).

Concentration of the investigated phytochemicals was scored as follows: - (no reaction), + (weakly positive reaction), ++ (positive reaction), +++ (important positive reaction).

Snails: Adult G. truncatula snails were used at a uniform size (3-5 $\mathrm{mm}$ in length). They were manually collected from El Melah river, in Ain Soltan oasis, Gafsa, a governorate in southwest Tunisia (34 $27^{\circ} 13^{\prime}$ ' N, 8 47’ 44” E), in April 2012. About 4,800 uninfected snails used for molluscicidal tests were extracted from the upstream of El Melah river barrage, where snails are already known to be uninfected as it is a high river and hence out of livestock's reach (HAMMAMI \& AYADI, 2008). However, about 210 naturally infected snails used for larvicidal activities were extracted downstream in the river. This downstream river was characterized by infested intermediate hosts, especially sheep and goats, and by snails showing two natural infection periods, in autumn and spring (HAMMAMI et al. 2007). All snails were transferred in plastic containers to the Fungal and Parasitic Molecular Biology Laboratory at the Faculty of Medicine in Sfax, Tunisia. They were cleaned and placed in holding tanks containing aerated, dechlorinated tap water and washed sand. They were kept alive under laboratory conditions: indoor temperature varying between 13 and $25^{\circ} \mathrm{C}$ with attenuated natural light and were fed on green algae. The 210 naturally infected snails raised in Laboratory, in spring (April 2012) were examined for cercarial shedding that extends over a period of approximately seven to 30 days.

Molluscicidal tests: The evaluation of the molluscicidal activities of the extracts and powders of $A$. inflata and $\mathrm{CuCl}_{2}$ (used as positive control) on snails was conducted as recommended by the World Health Organization (1965). Different concentrations of aqueous solutions were prepared for each extract, powder and $\mathrm{CuCl}_{2}$. Disinfected snails were exposed, in groups of 10 (five replicates) for $48 \mathrm{~h}$ (exposure period), to $500 \mathrm{~mL}$ of each concentration of the material to be tested: powders and extracts as listed in Table 3. Similarly, five groups of ten snails immersed in dechlorinated water were used as negative controls. After exposure, 


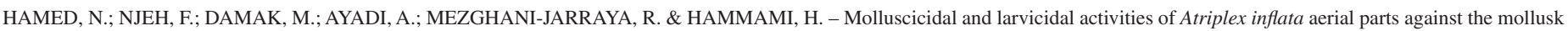
Galba truncatula, intermediate host of Fasciola hepatica. Rev. Inst. Med. Trop. Sao Paulo, 57(6):473-9, 2015.

snails were rinsed thoroughly in dechlorinated water and left for 48 $\mathrm{h}$ (recovery period) inside. Mortality was recorded after 24 and $48 \mathrm{~h}$. Dead animals were removed immediately to avoid the contamination of other animals. Snail mortality was established by the retraction of the body within the shell; no response to a needle probe was taken as evidence of death.

Larvicidal tests: Each snail that was assumed to be infested was placed individually in a Petri dish with algae and dechlorinated water. The positivity of each snail was confirmed by cercarial shedding observed under a stereomicroscope. Cercarial shedding was produced by thermal shock which is provoked according to RONDELAUD et al. 2013 and VIGNOLES et al. 2014.

The infected snails were exposed to the four potent $\mathrm{LC}_{90}$ molluscicidal extracts; corresponding to the leaves and fruits (ethyl acetate of leaves, hexane of leaves, ethyl acetate of fruits and hexane of fruits); in a group of 20 naturally infected snails (3.5-5 $\mathrm{mm}$ in length). The activity of each molluscicidal extract was interrupted after $48 \mathrm{~h}$ by placing snails in dechlorinated water. A group of 20 naturally infected snails, not exposed to molluscicides and placed only in dechlorinated water, was used as a control. After dissection, snail bodies were removed and placed in $200 \mathrm{~mL}$ of dechlorinated water. The cercariae, rediae, and intraredial germinal masses, which appear after dissection or leave the bodies of dissected molluscs, were observed under an optical microscope and then counted. Deteriorated larval stages were identified by their surface alteration and vesiculation (RUG \& RUPPEL 2000). The number of the deteriorated and undeteriorated larval stages (rediae, cercariae and intraredial germinal masses) were counted in each snail; then the delay rate was calculated.

Statistics: Concentrations that would kill $50 \%\left(\mathrm{LC}_{50}\right)$ or $90 \%$ $\left(\mathrm{LC}_{90}\right)$ of the exposed snails and the confidence intervals $(95 \% \mathrm{CI})$ were determined by WinDL software (MARTIN et al. 2003). Student's t-test was used to compare the alteration of different larval stages of the parasite (cercariae, rediae and intraredial germinal masses) after treatment with active samples (ZIMMERMAN et al. 1993).

\section{RESULTS}

Masses and yields of different aerial part extracts of $A$. inflata after 48 $\mathrm{h}$ of extraction, using increasing polarity solvents, are given in Table 1 . Yields vary between 0.05 and $1.17 \%$ for hexane extracts, between 1.20 and $3.73 \%$ for ethyl acetate extracts, between 1.89 and $26.51 \%$ for methanol extracts, and between 0.17 and $4.18 \%$ for hydromethanol extracts. The most important yield was obtained in the methanol extract from the leaves.

Phytochemical tests performed on each extract are reported in Table 2. Molluscicidal activities of each tested plant material are shown in Table 3

Table 1

Masses and yields of different aerial parts extracts of Atriplex inflata after 48h of extraction with increasing polarity solvents

\begin{tabular}{|c|c|c|c|c|c|}
\hline & & Hexane extract & $\begin{array}{l}\text { Ethyl acetate extract } \\
(\text { EtOAc) }\end{array}$ & $\begin{array}{l}\text { Methanol extract } \\
(\mathrm{MeOH})\end{array}$ & $\begin{array}{c}\text { Methanol- Water extract } \\
\qquad(8: 2, \mathrm{v}-\mathrm{v})\end{array}$ \\
\hline \multirow{2}{*}{ Leaves (125 g) } & Mass (g) & 1.46 & 1.50 & 33.14 & 5.22 \\
\hline & Yield (\%) & 1.17 & 1.20 & 26.51 & 4.18 \\
\hline \multirow{2}{*}{$\begin{array}{l}\text { Fruits } \\
(270 \mathrm{~g})\end{array}$} & Mass (g) & 0.14 & 10.07 & 5.10 & 0.46 \\
\hline & Yield (\%) & 0.05 & 3.73 & 1.89 & 0.17 \\
\hline
\end{tabular}

Table 2

Chemical compounds present in the extracts of aerial parts from Atriplex inflata

\begin{tabular}{|c|c|c|c|c|c|c|c|c|c|c|c|c|c|c|}
\hline \multirow[t]{2}{*}{$\begin{array}{l}\text { Aerial } \\
\text { parts }\end{array}$} & \multirow[t]{2}{*}{$\begin{array}{c}\text { Solvents of } \\
\text { extraction }\end{array}$} & \multicolumn{2}{|c|}{$\begin{array}{l}\text { Sterols and/or } \\
\text { triterpenoids }\end{array}$} & \multicolumn{2}{|c|}{ Flavonoids } & \multicolumn{2}{|c|}{ Saponins } & \multicolumn{2}{|c|}{ Alkaloids } & \multicolumn{2}{|c|}{ Coumarins } & \multirow{2}{*}{$\begin{array}{c}\text { Tannins } \\
*\end{array}$} & \multirow{2}{*}{$\begin{array}{c}\text { Tropolone } \\
*\end{array}$} & \multirow{2}{*}{$\begin{array}{c}\text { Quinones } \\
*\end{array}$} \\
\hline & & $*$ & $* *$ & $*$ & $* *$ & $*$ & $* *$ & $*$ & $* *$ & $*$ & $* *$ & & & \\
\hline \multirow[t]{4}{*}{ Leaves } & Hexane & ++ & + & - & - & - & - & - & - & - & - & - & - & - \\
\hline & EtOAc & + & + & - & - & + & - & - & - & - & - & - & - & - \\
\hline & $\mathrm{MeOH}$ & - & - & + & + & - & - & - & - & + & + & - & - & - \\
\hline & $\mathrm{MeOH}-\mathrm{H}_{2} \mathrm{O}$ & - & - & + & + & ++ & + & - & - & - & - & - & - & - \\
\hline \multirow[t]{4}{*}{ Fruits } & Hexane & ++ & + & - & - & - & - & - & - & - & - & - & - & - \\
\hline & EtOAc & + & ++ & - & - & - & - & - & - & - & - & - & - & - \\
\hline & $\mathrm{MeOH}$ & - & - & + & + & + & + & - & - & - & - & - & - & - \\
\hline & $\mathrm{MeOH}-\mathrm{H}_{2} \mathrm{O}$ & - & - & ++ & ++ & ++ & + & - & - & - & - & - & - & - \\
\hline
\end{tabular}

- : No reaction; +: Weak presence; ++: Presence; +++: Richness. EtOAc: Ethyl acetate; MeOH: Methanol; MeOH-H O: Methanol-Water (8-2: v-v). * : Colour reaction results. $* *$ TLC plate revelation results. 
HAMED, N.; NJEH, F.; DAMAK, M.; AYADI, A.; MEZGHANI-JARRAYA, R. \& HAMMAMI, H. - Molluscicidal and larvicidal activities of Atriplex inflata aerial parts against the mollusk Galba truncatula, intermediate host of Fasciola hepatica. Rev. Inst. Med. Trop. Sao Paulo, 57(6):473-9, 2015.

Table 3

Molluscicidal activities of Atriplex inflata extracts against Galba truncatula.

\begin{tabular}{|c|c|c|c|c|c|c|c|c|c|}
\hline \multirow[b]{2}{*}{ Organs } & \multirow[b]{2}{*}{ Powder/Solvent } & \multicolumn{4}{|c|}{ After $24 \mathrm{~h}$ action } & \multicolumn{4}{|c|}{ After $48 \mathrm{~h}$ action } \\
\hline & & $\begin{array}{l}\text { Equation of the line } \\
\text { weighed regression }\end{array}$ & Slope & $\begin{array}{l}\mathrm{LC}_{50}(\mathrm{mg} / \mathrm{L}) \\
(95 \% \mathrm{CI})\end{array}$ & $\begin{array}{l}\mathrm{LC}_{90}(\mathrm{mg} / \mathrm{L}) \\
(95 \% \mathrm{CI})\end{array}$ & Regression & Slope & $\begin{array}{l}\mathrm{LC}_{50}(\mathrm{mg} / \mathrm{L}) \\
(95 \% \mathrm{CI})\end{array}$ & $\begin{array}{l}\mathrm{LC}_{90}(\mathrm{mg} / \mathrm{L}) \\
(95 \% \mathrm{CI})\end{array}$ \\
\hline \multirow{5}{*}{ Leaves } & Powder & $Y=-5.22+3.65 X$ & 1.87 & $\begin{array}{c}26.79 \\
(1.45 ; 37.48) \\
\end{array}$ & $\begin{array}{c}60.08 \\
(44.36 ; 381.33) \\
\end{array}$ & $Y=-4.45+3.35 X$ & 1.98 & $\begin{array}{c}21.39 \\
(7.79 ; 58.73) \\
\end{array}$ & $\begin{array}{c}51.62 \\
(34.61 ; 76.98) \\
\end{array}$ \\
\hline & Hexane & $Y=-2.75+2.61 X$ & 2.41 & $\begin{array}{c}11.31 \\
(1.60 ; 79.85) \\
\end{array}$ & $\begin{array}{c}35.07 \\
(17.29 ; 71.14) \\
\end{array}$ & $Y=-3.42+3.88 X$ & 1.80 & $\begin{array}{c}7.59 \\
(4.70 ; 9.95) \\
\end{array}$ & $\begin{array}{c}16.25 \\
(12.26 ; 29.23) \\
\end{array}$ \\
\hline & EtOAc & $Y=-5.34+6.59 X$ & 1.41 & $\begin{array}{c}6.45 \\
(4.46 ; 7.71)\end{array}$ & $\begin{array}{c}10.08 \\
(8.39 ; 15.69)\end{array}$ & $Y=-5.69+7.38 X$ & 1.40 & $\begin{array}{c}5.90 \\
(3.63 ; 7.13)\end{array}$ & $\begin{array}{c}8.80 \\
(7.29 ; 13.51)\end{array}$ \\
\hline & $\mathrm{MeOH}$ & - & - & - & - & - & - & - & - \\
\hline & $\mathrm{MeOH}-\mathrm{H}_{2} \mathrm{O}$ & $Y=-5.74+3.22 X$ & 2.04 & $\begin{array}{c}61.64 \\
(34.16 ; 111.22) \\
\end{array}$ & $\begin{array}{c}137.58 \\
(34.07 ; 555.55) \\
\end{array}$ & $Y=-5.50+3.17 X$ & 2.06 & $\begin{array}{c}54.12 \\
(32.77 ; 89.38) \\
\end{array}$ & $\begin{array}{c}137.09 \\
(29.17 ; 644.24) \\
\end{array}$ \\
\hline \multirow{6}{*}{ Fruits } & Powder & $Y=-5.69+3.51 X$ & 1.92 & $\begin{array}{c}41.57 \\
(25.95 ; 52.47) \\
\end{array}$ & $\begin{array}{c}96.27 \\
(71.47 ; 248.18) \\
\end{array}$ & $Y=-7.61+5.02 X$ & 1.57 & $\begin{array}{c}32.76 \\
(24.30 ; 39.23) \\
\end{array}$ & $\begin{array}{c}58.95 \\
(48.19 ; 91.08) \\
\end{array}$ \\
\hline & Hexane & $Y=-5.24+6.28 X$ & 1.44 & $\begin{array}{c}7.16 \\
(4.51 ; 8.44) \\
\end{array}$ & $\begin{array}{c}10.28 \\
(8.70 ; 17.16) \\
\end{array}$ & $Y=-5.13+6.27 X$ & 1.44 & $\begin{array}{c}6.69 \\
(4.76 ; 7.68)\end{array}$ & $\begin{array}{c}8.58 \\
(7.49 ; 13.00)\end{array}$ \\
\hline & EtOAc & $Y=-5.91+6.32 X$ & 1.44 & $\begin{array}{c}8.61 \\
(5.42 ; 13.69) \\
\end{array}$ & $\begin{array}{c}13.03 \\
(9.88 ; 17.19) \\
\end{array}$ & $Y=-5.63+6.36 X$ & 1.43 & $\begin{array}{c}7.32 \\
(3.11 ; 17.52) \\
\end{array}$ & $\begin{array}{c}11.16 \\
(8.06 ; 15.45) \\
\end{array}$ \\
\hline & $\mathrm{MeOH}$ & - & - & - & - & - & - & - & - \\
\hline & $\mathrm{MeOH}-\mathrm{H}_{2} \mathrm{O}$ & - & - & - & - & - & - & - & - \\
\hline & Dechlorinated water & - & - & - & - & - & - & - & - \\
\hline
\end{tabular}

CI: confidence interval; $\mathrm{LC}_{50}: 50 \%$ lethal concentration; $\mathrm{LC}_{90}: 90 \%$ lethal concentration; -: no activity. $\mathrm{CuCl}_{2}$ showed molluscicidal activity against $\mathrm{G}$. truncatula after 48 h with: $\mathrm{LC}_{50}=26.12(19.35 ; 31.69) \mathrm{mg} / \mathrm{L}$ and $\mathrm{LC}_{90}=62.71 \mathrm{mg} / \mathrm{L}(49.83 ; 96.50)$. EtOAc: Ethyl Acetate; $\mathrm{CH}_{2} \mathrm{Cl}_{2}:$ Methylene Chloride; MeOH: Methanol; MeOH$\mathrm{H}_{2} \mathrm{O}$ : Methanol-Water.

Molluscicidal activity: The highest molluscicidal activities were detected for hexane and ethyl acetate extracts of $A$. inflata leaves and fruits giving closer respective $\mathrm{LC}_{50}$ of 7.59, 6.69, 5.90 and 7.32 $\mathrm{mg} / \mathrm{L}$ after $48 \mathrm{~h}$ of treatment. Meanwhile, methanol and hydromethanol extracts of leaves and fruits were considered inactive because their $\mathrm{LC}_{50}$ exceeded 40 $\mathrm{mg} / \mathrm{L}$ or was zero according to the WHO (1993). Weaker molluscicidal activities were recorded in powders with $\mathrm{LC}_{50}$ of $21.39 \mathrm{mg} / \mathrm{L}$ for leaves and $32.76 \mathrm{mg} / \mathrm{L}$ for fruits. Copper chloride used as positive control showed a molluscicidal activity with an $\mathrm{LC}_{50}$ of $26.12 \mathrm{mg} / \mathrm{L}$ against G. truncatula after $48 \mathrm{~h}$ of treatment (Table 3). G. truncatula negative control organisms were not affected by dechlorinated water after $48 \mathrm{~h}$ of exposure. Hemolysis and hypersecretion of mucus were the common toxic reactions of snails to the active tested materials.
Chemical tests performed on the extracts for sterols and/or triterpenoids were positive, particularly for ethyl acetate extract of leaves. Methanolic and hydromethanolic extracts were inactive against G. truncatula and did not contain any sterols and/or triterpenoids, but contained flavonoids instead.

Larvicidal activity: Delay rates (\%) of larval stages: cercariae, rediae and intraredial germinal masses in infected G. truncatula after $48 \mathrm{~h}$ of exposure to molluscicidal extracts of $A$. inflata and in untreated infected snails placed in dechlorinated water are listed in Table 4 . The four most potent $A$. inflata molluscicidal extracts were toxic to the larval stages of $F$. hepatica. The hexane extract from fruits was significantly more toxic to intraredial germinal masses than the others $(p<0.05)$.

Table 4

Deterioration rates (\%) of cercariae, rediae and intraredial germinal masses in infected Galba truncatula after $48 \mathrm{~h}$ of exposure to molluscicidal extracts of Atriplex inflata and in untreated infected snails placed in dechlorinated water

\begin{tabular}{|c|c|c|c|c|c|c|c|c|c|c|c|}
\hline \multicolumn{5}{|c|}{$\%$ deterioration } & \multirow{3}{*}{$\begin{array}{c}\text { Dechlori- } \\
\text { nated water }\end{array}$} & \multirow{3}{*}{$\mathrm{a} / \mathrm{b}$} & \multicolumn{3}{|c|}{$p$ value } & \multirow{3}{*}{$\mathrm{b} / \mathrm{d}$} & \multirow{3}{*}{$\mathrm{c} / \mathrm{d}$} \\
\hline & \multicolumn{2}{|c|}{ EtOAc extracts } & \multicolumn{2}{|c|}{ Hexane extracts } & & & $\mathrm{a} / \mathrm{c}$ & $\mathrm{a} / \mathrm{d}$ & $\mathrm{b} / \mathrm{c}$ & & \\
\hline & Leaves (a) & Fruits (b) & Fruits (c) & Leaves (d) & & & & & & & \\
\hline Rediae & $69.58 \pm 5.56$ & $45.5 \pm 6.34$ & $81.25 \pm 23.93$ & $61.26 \pm 26.56$ & 0 & 0.0039 & 0.2200 & 0.3100 & 0.0280 & 0.1850 & 0.1530 \\
\hline Intraredial germinal masses & $78.47 \pm 7.33$ & $59.38 \pm 15.86$ & $98.92 \pm 1.86$ & $92.73 \pm 8.94$ & 0 & 0.0658 & 0.0047 & 0.0490 & 0.00639 & 0.0169 & 0.1520 \\
\hline Cercariae & $89.32 \pm 22.57$ & $65.09 \pm 27.97$ & $59.92 \pm 26.89$ & $54.48 \pm 22.10$ & 0 & 0.0230 & 0.0081 & 0.0013 & 0.3390 & 0.1790 & 0.3130 \\
\hline
\end{tabular}

$p: p$ value calculated comparing: $\mathrm{a}$ to $\mathrm{b} ; \mathrm{b}$ to $\mathrm{c}$ and a to $\mathrm{c}$. 


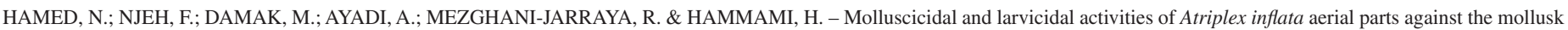
Galba truncatula, intermediate host of Fasciola hepatica. Rev. Inst. Med. Trop. Sao Paulo, 57(6):473-9, 2015.

\section{DISCUSSION}

The high cost of synthetic molluscicides, their toxicity to non-target organisms, and even human beings as well as the complex organization required in their application has hindered their continuous use in fasciolosis control programs. Many plants have been screened for their intrinsic molluscicidal properties in an attempt to find an alternative to synthetic ones (HASSAN et al. 2011). In previous studies, some species of Atriplex have been found to have biological activities such as antiinflammatory potency (ATEYA et al.2005), insecticidal activity against Tribolium spp. (TRABELSI 2004), and antiviral efficiency against Herpes simplex infection (BEN SASSI et al. 2008). Antifungal activity of the same plant against Aspergillus fumigatus and three Fusarium species was also proved. Besides, antibacterial activity (against Bacillus subtilis and Staphylococcus aureus), antidiabetic, and antioxidant activities was described (MOHAMMED et al. 2012). In addition, a hepato-renal protective effect of A. lindleyi Moq. aerial parts against bromobenzene (BB) intoxication in rats was described (MATLOUB et al. 2011). Other studies have investigated several Atriplex species for their cytotoxicity, such as A. confertifolia and A. lindleyi Moq (CAPUA et al. 2010; MATLOUB et al. 2014).

Some Atriplex species have been found to have a strong molluscicidal activity which varies greatly from one species to another and even among parts of the same plant (SILVA et al. 2005).

Taking these facts into consideration, together with the increase of morbidity, mortality and treatment cost, we decided in the present research to study $A$. inflata phytochemical composition, as well as its molluscicidal and larvicidal potencies.

Hexane and ethyl acetate extracts of $A$. inflata leaves and fruits showed remarkable molluscicidal activities which ranged between 5.90 and $7.59 \mathrm{mg} / \mathrm{L}$. Ethyl acetate leaves extracts showed the highest molluscicidal activity with $\mathrm{LC}_{50}$ of $5.90 \mathrm{mg} / \mathrm{L}$ after $48 \mathrm{~h}$ of exposure. These values were significantly more important than the mortality caused by copper chloride. Powders were less active than extracts. These results belong to the reports of CHRISTENSEN \& OMAR (1985), BAKRY (2009), TANTAWY (2002) SHOEB et al. (1987) who revealed that the molluscicidal activities of other Atriplex species vary from one species to another.

It was demonstrated that $A$. stylosa gave $\mathrm{LC}_{50}$ between 31 and $74 \mathrm{mg} / \mathrm{L}$ in various solvents against $B$. alexandrina (BAKRY 2009). This result is not that important compared to A. inflata, because lethal concentrations should fall well below the upper threshold of $40 \mathrm{mg} / \mathrm{L}$ according to the WHO guidelines (1993). Moreover, A. ambriosides was considered to be a potent molluscicide against Bulinus truncatus with $\mathrm{LC}_{50}$ varying between $1.41 \mathrm{mg} / \mathrm{L}$ and $14.12 \mathrm{mg} / \mathrm{L}$ after $24 \mathrm{~h}$. These values are remarkable, compared to the molluscicidal potency of $A$. inflata. These differences in potency may be attributed to several factors including the location of the plant species, the collection time of the plant sample, the used part, the storage conditions, the method of extraction and the solvent type (BRACKENBURY \& APPLETON 1997, HASSAN et al. 2010).

In addition to its remarkable molluscicidal potency, $A$. inflata reveals some interesting characteristics for an ideal molluscicide plant. It is a nontoxic plant that belongs to the genus Atriplex, which is widespread in different parts of the world. This genus is also regarded as a workable group on a generic level (MOHAMMED et al. 2012, OSMOND et al. 1980).

In this study, extracts with a notable molluscicidal activity contained sterols and/or triterpenoids. In a previous scientific research, triterpenoids and steroids were isolated from the petroleum ether extract of $A$. inflata (MATLOUB et al. 2011). We can deduce that the important molluscicidal activities observed in this study may be attributed to the presence of triterpenoids and/or steroids.

In our study, the hydroethanol extracts of the leaves and the fruits of $A$. inflate, rich in flavonoids, were not active. Likewise, ATEYA et al. (2005), EL SAKHAWY et al. (2013), and MOHAMMED et al. (2012) have isolated some flavonoids from the hydroethanol extract of the aerial parts of A. inflata. However, in other studies, it was reported that rutin and quercetin, isolated respectively from Calendula officinalis and Bauhinia variegata plants, were flavonoids having molluscicidal activities: rutin was found to be powerful against Biomphalaria alexandrina, Bulinus truncatus and Lymnaea snails (EL-SHEIKH et al. 2012); while, quercetin was active against Lymnaea acuminata with a $\mathrm{LC}_{50}$ of $9.86 \mathrm{mg} / \mathrm{L}$ (SINGH et al. 2012)

Taking the larvicidal activity of $A$. inflata into consideration, hexane and ethyl acetate extracts of both aerial organs, leaves and fruits, used at lethal concentrations to the mollusk $G$. truncatula also gave potent larvicidal activities with delay rates exceeding $45.5 \%$. The use of these extracts seems to be very helpful in eliminating both the intermediate host and the larval stages of the parasite $F$. hepatica.

The high rate of toxicity of the fruits hexane extract to rediae, intraredial germinal masses and cercariae may be attributed to the high level of triterpenoids and/or steroids contained in these fruits.

\section{CONCLUSION}

In the present study, hexane and ethyl acetate extracts of $A$. inflata $\mathrm{F}$. Muell. aerial parts showed potent molluscicidal and larvicidal activities against the snail gastropoda $G$. truncatula and larvicidal activity against F. hepatica larval stages, according to the World Health Organization guidelines for hexane extracts of leaves and fruits. Molluscicidal activities of powders were less potent on snails, but active according to the same guidelines. Phytochemical tests showed that these activities may be attributed to the presence of triterpenoids and/or sterols.

The use of these extracts may provide additional arsenal to the control methods of snail transmitting fasciolosis in both the tropical and the third world countries where fasciolosis is a common disease.

\section{RESUMO}

Atividade moluscicida e larvicida das partes aéreas de Atriplex inflata contra o molusco Galba truncatula, hospedeiro intermediário da Fasciola hepatica

Fasciolose é uma parasitose generalizada que ocorre em animais de fazendas em muitos países em desenvolvimento. Por esta razão, é necessária a busca de novas substâncias contra as doenças parasitárias 
HAMED, N.; NJEH, F.; DAMAK, M.; AYADI, A.; MEZGHANI-JARRAYA, R. \& HAMMAMI, H. - Molluscicidal and larvicidal activities of Atriplex inflata aerial parts against the mollusk Galba truncatula, intermediate host of Fasciola hepatica. Rev. Inst. Med. Trop. Sao Paulo, 57(6):473-9, 2015.

causadas por vermes. De fato, uma grande variedade de plantas terrestres foi objeto de testes farmacológicos e químicos a fim de descobrir o seu potencial para utilização em terapêutica humana. As atividades moluscicida e larvicida de Atriplex inflata foram testadas contra estágios larvários de Galba truncatula e Fasciola hepatica infectando este caracol na Tunísia. Testes fitoquímicos foram realizados com extratos a fim de estabelecer uma relação significativa com as atividades moluscicida e larvicida. A atividade moluscicida foi avaliada submetendo os caracóis a soluções aquosas. Conforme o caso, hexano, acetato de etilo, metanol e metanol-água (8:2, v-v) foram utilizados como solventes de extração. Como resultado, hexano e extratos de acetato apresentaram atividades potentes de acordo com a Organização Mundial de Saúde, resultando em LC50 = 7,59 mg/L e 6,69 mg/L para extratos de hexano de folhas e frutos, respectivamente. Extratos de acetato de etilo resultaram em $\mathrm{LC} 50=5,90 \mathrm{mg} / \mathrm{L}$ e $7,32 \mathrm{mg} / \mathrm{L}$ para as folhas e frutos sucessivamente. Atividades moluscicidas das substâncias sob a forma de pó foram menos potentes em caracóis, mas ativas de acordo com a Organização Mundial de Saúde. Hexano e extratos de acetato de folhas e frutos apresentaram atividade larvicida potente, com uma taxa de atraso superior a 45,50\% (45,50-98,92\%). Testes fitoquímicos mostraram que estas atividades podem ser atribuídas à presença de triterpenóides e/ou esteróis.

\section{ACKNOWLEDGMENTS}

This study was funded by the Ministry of Higher Education, Scientific Research, and Information and Communication Technologies of Tunisia.

\section{REFERENCES}

1. Abdul-Samie RE, Soliman OS, El-Nemr H, Masou A. Study of $\mathrm{Il}_{1} \mathrm{~b}, \mathrm{Il}_{4}, \mathrm{Il}_{5}$ and Ige before and after Mirazid therapy in children with intestinal schistosomiasis and fascioliasis. NY Sci J. 2010;3:116-22.

2. Akinjogunla OJ, Yah CS, Eghafona NO, Ogbemudia FO. Antibacterial activity of leave extracts of Nymphaea lotus (Nymphaeaceae) on Methicillin resistant Staphylococcus aureus (MRSA) and Vancomycin resistant Staphylococcus aureus (VRSA) isolated from clinical samples. Ann Biol Res. 2010;1:174-84.

3. Ateya AMM, El-Shafae AM, El-Shazly AM, Hemdan DE. Antihepatotoxic, antiinflammatory, antimicrobial activities and chemical constituents of Atriplex Inflata. Bull Fac Pharm Cairo Univ. 2005;43:265-72.

4. Ayadi A, Ben Rachid MS, Kannou H, Bradai K, Rondelaud D. Étude épidémiologique sur un foyer de distomatose à $F$. hepatica $\mathrm{L}$. dans les oasis de Tozeur (Tunisie). Bull Soc Fr Parasitol. 1993;11:217-22.

5. Ayadi A, Makni F, Ben Saïd M. État actuel de la fasciolose en Tunisie. Bull Soc Fr Parasitol. 1997;15:27-32.

6. Ayadi A, Sellami H, Dani A, Bardaii K, Hachicha M, Triki A. Les manifestations neurologiques de la distomatose hépatique à Fasciola hepatica. Arch Inst Pasteur Tunis. 1991;68:275-83.

7. Bakry FA. Use of some plant extracts to control Biomphalaria alexandrina snails with emphasis on some biological effects. Pestic Biochem Physiol. 2009;95:159-65.

8. Békro YA, Békro JAM, Boua BB, Tra Bi FH, Ehilé EE. Étude ethnobotanique et screening phytochimique de Caesalpinia benthamiana (Bail) Herend. et Zarucchi (Caesalpiniaceae). Sci Nat. 2007;4:217- 25.

9. Ben Sassi A, Harzallah-Skhiri F, Bourgougnon N, Aouni M. Antiviral activity of some Tunisian medicinal plants against Herpes simplex virus type 1. Nat Prod Res. 2008:22:53-65.
10. Brackenbury TD, Appleton CC. Acute toxicity evaluation of the plant molluscicide, Apodytes dimidiata (Icacinaceae), to Eisenia fetida (Oligochaeta) and Oreochromis mossambicus (Cichlidae) in South Africa. Acta Trop. 1997;63:1-14.

11. Capua CJ, Hopson NP, Stewart CMM, Johnston GR, O’Neill KL, Schaalje GB, et al. Cytotoxicity of Atriplex confertifolia. J Toxicol. 2010;2010:976548.

12. Glowniak K, Widelski J. Coumarins: TLC analysis. In: Cazes J, editor. Encyclopedia of chromatography. $3^{\text {rd }}$ ed. Boca Raton: CRC Press; 2009. p. 511.

13. Chaieb M, Boukhris M. Flore succincte et illustrée des zones arides et sahariennes de Tunisie. Sfax: SIMPACT Press; 1998.

14. Christensen SB, Omar AA. Atriplex nummularia, a source for the molluscicide saponins: hederagenin-3-O- $\beta$-D-glucuronopyranoside and calenduloside E. J Nat Prod. 1985;48:161.

15. El-Sakhawy FS, Abou-Hussein DR, El-Kersh DM, Sleem AA. Anabolic and androgenic effects of certain Atriplex species grown in Egypt. Egypt J Biomed Sci. 2013;40:97.

16. El-Sheikh YWA, Eltamny HM, Soliman HA, Farag AA, El Behary MHH. Molluscicidal activity of eco-friendly natural compound (Rutin) gained from ethanolic flowers extract of Calendula officinalis on B. alexandrina, B. truncatus and Lymaned snails. NY Sci J. 2012;5:19-27.

17. Hammami H, Ayadi A. Ecologie de Lymnaea truncatula Müller, hôte intermédiaire de Fasciola hepatica Linné dans le microclimat de Tozeur (sud-ouest de la Tunisie). Bull Soc Pathol Exot. 1999; 92:302-4.

18. Hammami H, Hamed N, Ayadi A. Epidemiological studies on Fasciola hepatica in Gafsa oases (South West of Tunisia). Parasite. 2007;14:261-4.

19. Hammami H, Ayadi A. Molluscicidal and antiparasitic activity of Solanum nigrum villosum against Galba truncatula infected or uninfected with Fasciola hepatica. J Helminthol. 2008;82:235-9

20. Hammami H, Mezghani-Jarraya R, Damak M, Ayadi A. Molluscicidal activity of various solvent extracts from Solanum nigrum var. villosum L. aerial parts against Galba truncatula. Parasite. 2011;18:63-70.

21. Harborne JB. Biochemistry of phenolic compounds. London: Academic Press; 1964 p. 93-111.

22. Harborne JB. Phytochemical methods. London: Chapman and Hall; 1973.

23. Harborne JB. Phytochemical methods. $3^{\text {rd }}$ ed. London: Chapman and Hall; 1998

24. Hassan AA, Mahmoud AE, Hassan RA, Huseein AM. Evaluation of Euphorbia aphylla, Ziziphus spina-christi and Enterolobium contortisiliquum as molluscicidal agents. J Am Sci. 2011;7:511-20.

25. Hassan SE, Abdel-Rahman EH, Abdel-Monem AR. Molluscicidal activity of butano fraction of Meryta denhamii flowers against Biomophalaria alexandrina and Lymnaea nalatensis. Global Vet. 2010;4:15-21.

26. Jemli MH, Rhimi I, Jdidi A, Mastouri L, Kilani M. La fasciolose ovine dans la région de Sejnane (Nord de la Tunisie). Rev Méd Vét. 1991;142:229-35.

27. Jigyasu HV, Sing VK. Effect of environmental factors on the fecundity, hatchability and survival of snail Lymnaea (Radix) acuminate (Lamarck): vector of fascioliasis. J. Water Health. 2010;8:109-15.

28. Le Floc'h E, Boulos L, Vela E. Catalogue synonymique commenté de la Flore De Tunisie. Tunis: Ministère de l'Environment et du Développement Durable, Banque Nationale de Gènes; 2010. 


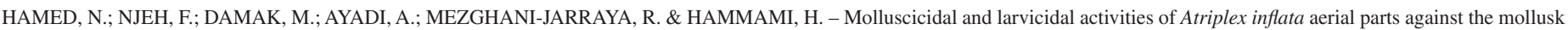
Galba truncatula, intermediate host of Fasciola hepatica. Rev. Inst. Med. Trop. Sao Paulo, 57(6):473-9, 2015.

29. Mage C, Bourgne H, Toullieu J M, Rondelaud D, Dreyfuss G. Fasciola hepatica and Paramphistomum daubneyi: changes in prevalences of natural infections in cattle and in Lymnaea truncatula from central France over the past 12 years. Vet Res. 2002;33:439-47.

30. Markham KR. Techniques of flavonoid identification. London: Academic Press; 1982.

31. Martin T, Ochou OG, Vaissayre M, Fournier D. Organophosphorus insecticides synergize pyrethroids in the resistant strain of cotton bollworm, Helicoverpa armigera (Hübner) (Lepidoptera: Noctuidae) from West Africa. J Econ Entomol. 2003;96:468 74.

32. Matloub AA, El Souda SS, Hamed MA. Phytoconstituent of petroleum ether Extrac of Atriplex lindleyi Moq. aerial part and its hepato -renal protection. Planta Med. 2011;77( PF36):1315.

33. Matloub AA, Hamed MA, El Souda SS. Chemo-protective effect on hepato-renal toxcicity and cytotoxic activity of lipoidal matter of Atriplex lindleyi Moq. Int J Pharm Pharm Sci. 2014;6:187-96.

34. Mello-Silva CC, Vasconcellos MC, Pinheiro J, Rodrigues MLA. Physiological changes in Biomphalaria glabrata Say 1818, (Pulmonata: Planorbidae) caused by sub-lethal concentrations of the latex of Euphorbia splendens var. hisloppii N.E.B. (Euphorbiaceae). Mem Inst Oswaldo Cruz. 2006;101:3-8.

35. Mohammed R, El-Hawary SS, Abo-Youssef AM, Biological investigation of some wild Aizoaceae and Chenopediaceae species growing in Egypt. J Nat Prod. 2012;5:193-206.

36. Onwukaeme DN, Ikuegbvweha TB, Asonye CC. Evaluation of phytochemical constituents, antibacterial activities and effect of exudate of Pycanthus Angolensis weld warb (Myristicaceae) on corneal ulcers in rabbits. Trop J Pharm Res. 2007;6:72530 .

37. Osmond CB, Björkman O, Anderson DJ. Systematic and geographical state of Atriplex. In: Physiological processes in plant ecology. Berlin: Springer-Verlag; 1980. p. $12-40$.

38. Rondelaud D, Tili A, Vignoles P, Mekroud A, Dreyfuss G. Consequence of temperature changes on cercarial shedding from Galba truncatula infected with Fasciola hepatica or Paramphistomum daubneyi. Parasite. 2013;20:10.
39. Rug M, Ruppel A. Toxic activities of the plant Jatropha curcas against intermediate snail hosts and larvae of schistosomes. Trop Med Int Health. 2000;5:423-30.

40. Shoeb HA, El-Emam MA, Saad AM, Mohamed MA. Molluscicidal activity of Fagonia cretica and Atriplex leucoclada. J Egypt Soc Parasitol. 1987;17:539-46.

41. Silva TMS, Batista MM, Camara CA, Agra MF. Molluscicidal activity of some Brazilian Solanum spp. (Solanaceae) against Biomphalaria glabrata. Ann Trop Med Parasitol. 2005;99:419-25.

42. Singh KL, Singh DK, Singh VK. Characterization of the molluscicidal activity of Bauhinia variegata and Mimusops elengi plant extracts against the Fasciola vector Lymnaea acuminata. Rev Inst Med Trop Sao Paulo. 2012;54:135-40.

43. Tantawy AA. Effect of sublethal concentrations of Atriplex halimus (Chenopodiaceae) on Biomphalaria alexandrina, the snail vector of Schistosoma mansoni in Egypt. J Egypt Soc Parasitol. 2002;32:297-305.

44. Trabelsi L. Activités biologiques, insecticides et fongicides des quelques halophytes des sebkhas de Hergla et de Monastir. Mastère en Protection des Plantes et Environnement de l'Institut Supérieur Agronomique. Chott Mariem: Université de Sousse; 2004

45. Vignoles P, Titi A, Rondelaud D, Mekroud A, Dreyfuss G. Fasciola hepatica: effect of the natural light level on cercarial emergence from temperature-challenged Galba truncatula. Parasite. 2014;21:8.

46. World Health Organization. Molluscicide screening and evaluation. Bull World Health Organ. 1965;33:567-81.

47. World Health Organization. The control of schistosomiasis. Second report of the WHO Expert Commitee. World Health Organ Tech Rep Ser. 1993;830:1-86.

48. Zimmerman DW, Zumbo BN, Rank transformations and the power of the Student $\mathrm{t}$ test and Welch t' test for non-normal populations. Can J Exp Psychol. 1993;47:52339.

Received: 21 September 2014

Accepted: 27 March 2015 


\section{LIBRARY OF THE \\ SÃO PAULO INSTITUTE OF TROPICAL MEDICINE}

Website: http://www.imt.usp.br/sobre-o-imtsp/biblioteca

Address: Biblioteca do Instituto de Medicina Tropical de São Paulo da Universidade de São Paulo Av. Dr. Enéas de Carvalho Aguiar, 470.

05403-000 - São Paulo - SP - Brazil.

Telephone: 5511 3061-7003
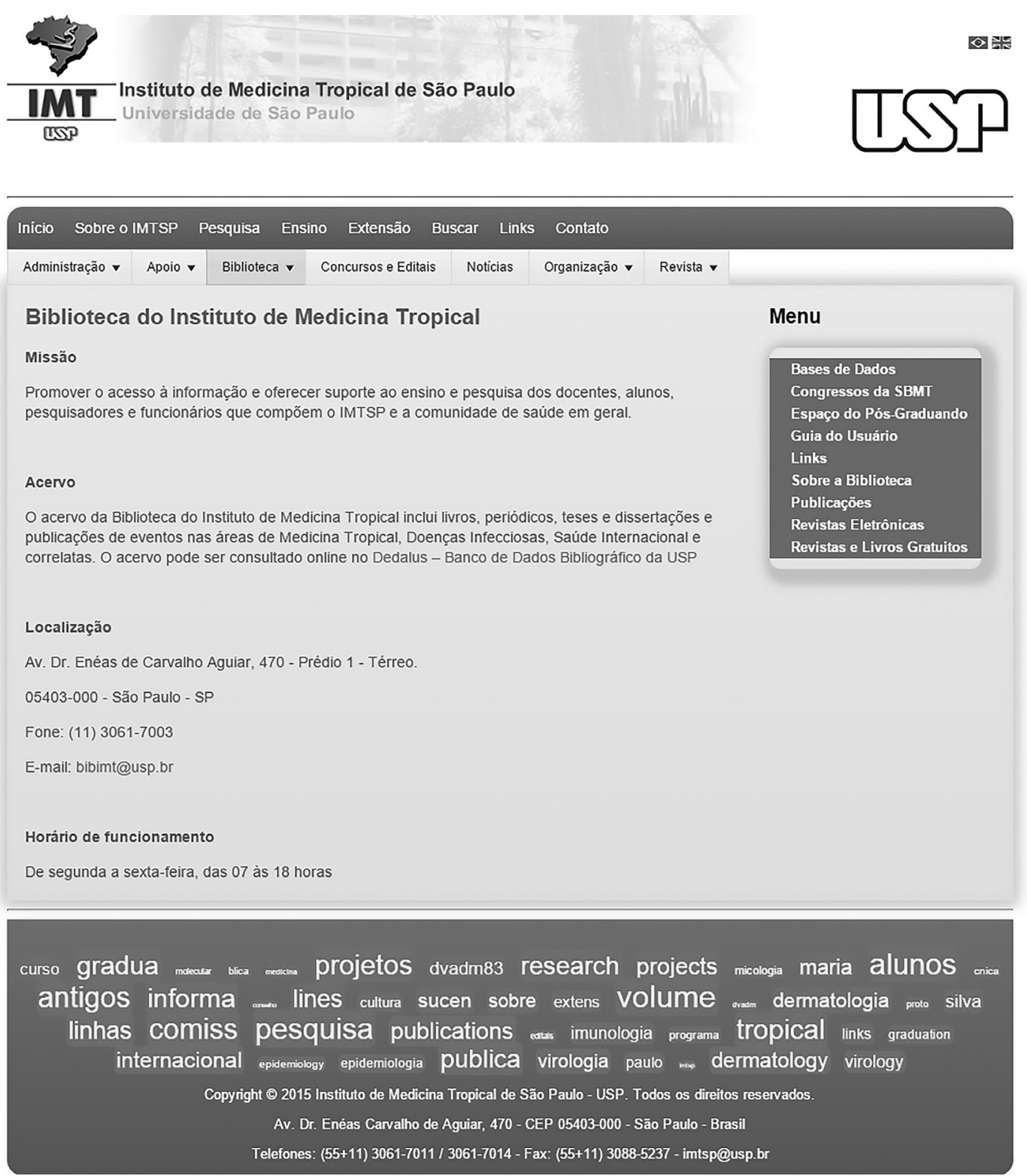

The Library of the São Paulo Institute of Tropical Medicine (IMTSP Library) was created on January 15, 1959 in order to serve all those who are interested in tropical diseases.

The IMTSP Library has a collection consisting of books, theses, annals of congresses, journals, and reference works.

The collection of the Library can be searched through the USP Bibliographic Database - Dedalus at the URL http://200.144.190.234/F 